\title{
The Genetic Variability of Sicilian Lemon Germplasm Revealed by Molecular Marker Fingerprints
}

\author{
Mirko Siragusa ${ }^{1}$, Fabio De Pasquale, Loredana Abbate, Letizia Martorana, and Nicasio Tusa \\ Institute of Plant Genetics—CNR, Research Division Palermo, Corso Calatafimi 414, I-90129 \\ Palermo, Italy
}

\begin{abstract}
Additional INDEX words. Citrus limon, genetic diversity, 'Femminello', 'Monachello', 'Lunario', ISSR, RAPD
Abstract. There is a high level of diversity among lemons [Citrus limon (L.) Burm. $\mathrm{f} .(2 \mathrm{n}=\mathbf{2 x}=\mathbf{1 8})]$ in Sicily, where each growing area has a wide range of landraces mostly derived from bud mutation. Because this variability represents an important resource for future breeding programs and genetic improvement, the relationships among the principal 36 accessions of Sicilian lemon, belonging to three different cultivars (Femminello, Monachello, and Lunario), were examined by intersimple sequence repeat and random amplified polymorphic DNA markers. Three 'Femminello' accessions from nearby Italian regions were also examined to study the genetic flow from the continent. The disputed case of the accession 'Eureka Messina lemon' was also examined, using 'Frost Eureka' as a control. Our results confirmed the extreme polymorphic nature of the three principal Sicilian cultivars and the presence of a wide range of different genotypes. Twenty-two Sicilian genotypes were recognized as unique accessions, reflecting the richness of the lemon germplasm present in Sicily. Each growing area showed the presence of several genetically different landraces, probably preserved by genetic isolation, whereas the continental accessions appeared extremely similar to the island genotypes, showing an exchange of germplasm from the island to the continent.
\end{abstract}

Lemon is an economically important crop widely grown in southern Italy and especially in Sicily, the first Italian region for lemon production (Cottone et al., 1996; Forte, 1999). While in the other principal producing countries one or few cultivars prevail over the others ('Eureka' and 'Lisbon' in the United States, 'Genoa' and 'Limoneira Lisbon' in Argentina, 'Galego' in Brazil and 'Berna' in Spain; Russo and Spina, 1985; Saunt, 2000), in Italy, each lemon-cultivating area (Palermo, Catania, Siracusa, Messina, Reggio Calabria, Salerno, and Naples) has a wide range of landraces mostly derived from bud mutation from the cultivar Femminello (Russo and Spina, 1985).

As the most domesticated fruit crop species over the past century, the Italian lemon has also suffered a dramatic reduction in the gene pool due to the best characteristics (high yields, good fruit size, high juice content, low seededness) of some grown cultivars and the presence of "mal secco" disease \{citrus wilt [Phoma tracheiphila (Petri) L.A. Kantachveli and Gikachvili]\}, which allowed only tolerant cultivars (such as Monachello) to survive (Crescimanno et al., 1992). Therefore, some landraces with interesting breeding characteristics are at risk of disappearance.

In recent years, the collection and the characterization of fruit crop germplasm has become a common concern among geneticists and breeders to identify and preserve the genetic diversity of species and for setting up new breeding programs aimed at genetic improvement.

Currently in Sicily, there are several lemon landraces with interesting agronomic traits, but little information is available

Received for publication 13 Sept. 2007. Accepted for publication 15 Jan. 2008 This research was supported by the research grant "Scrigno Project" (Develop and Characterization of Genetic Resources Native in Market Gardening) from Ministry of University and Research (MIUR).

${ }^{1}$ Corresponding author. E-mail: mirko.siragusa@igv.cnr.it. about their genetic variability. Until now, Sicilian lemon characterization has been done only through phenotypic analysis (Crescimanno et al., 1992). This characterization requires a large set of data, which is often difficult to access, and in some cases, dependent upon environmental conditions.

Polymerase chain reaction (PCR)-based DNA marker technology has already become a useful tool in characterizing lemon cultivars. In particular, PCR methods using arbitrary primers have become very popular, as they do not require any information about DNA sequences in addition to being costand time-effective (Fang and Roose, 1997).

Fang and Roose (1997) used intersimple sequence repeat (ISSR) to discriminate between five genotypes of the cultivars Eureka and Lisbon, whereas Gulsen and Roose (2001a) used ISSR, microsatellites, and isozymes to assess diversity and phylogenetic relationships in several lemon accessions and related taxa. Recently, 10 autochthonous lemon cultivars of the Italian region Campania were identified through ISSR (Capparelli et al., 2004) and random amplified polymorphic DNA (RAPD) techniques (Mariniello et al., 2004).

Phylogenetic relationships between lemon and other Citrus L. species and Citrus-related genera have been also investigated by SSR (Barkley et al., 2006), RAPD, and restriction fragment length polymorphism (Federici et al., 1998; Nicolosi et al., 2000).

In the present study, 41 phenotypically diverse lemon accessions, mostly collected from different parts of Sicily, were analyzed by ISSR and RAPD methods to detect genetic polymorphisms useful for setting up a molecular reference system that would allow precise identification. Data obtained from this study have been also used to provide much information about genetic relationships among the accessions examined. This information, with morphological and phenological descriptors, could be useful in assessing the basis of breeding programs aimed at the genetic improvement of lemons. 


\section{Materials and Methods}

Plant materials and DNA extraction. A total of 41 plants of C. limon, including 34 'Femminello', 3 'Monachello', 2 'Lunario', and 2 'Eureka' accessions were used in the investigation. The sampling sites, the codes, and the more remarkable quality traits are listed in Table 1. The terms 'Femminello', 'Monachello', and 'Lunario' commonly are used to identify different cultivars, each constituted from a phenotypically diverse, wide range of plants. Thirty-one 'Femminello', three 'Monachello', and two 'Lunario' accessions differing in morphological and physiological traits were collected from several sites located in the major Citrus diffusion areas of Sicily. The localization of the sampling sites of Sicilian plants is shown in Fig. 1. Two 'Femminello' plants, 'Femminello a foglia larga' (FW) and 'Femminello Favazzina' (FV), were collected from Calabria region, the closest peninsular Italian region to Sicily, whereas a 'Femminello common' (FC7) was collected from Salerno (Campania region). Among the two 'Eureka' accessions, only 'Frost Eureka' (EF) was certified, and it was used as external control. The 'Eureka Messina lemon' (EM) was a putative 'Eureka' plant collected from a grower in the Siracusa area. All the plants were introduced in the germplasm collection in the Lascari field station (lat. $38^{\circ} \mathrm{N}$, long. $14^{\circ} \mathrm{E}$ ).

Genomic DNA was extracted from leaves as described by Doyle and Doyle (1987). The leaves were collected from mature trees present in the germplasm collection and were carefully washed (as advised to avoid insects and fungal contamination; Fang and Roose, 1997), frozen in liquid nitrogen, and stored at $-80{ }^{\circ} \mathrm{C}$. The samples were ground in a mortar with liquid nitrogen. DNA was quantified by measuring $\mathrm{OD}_{260}$ as described by Sambrook et al. (1989).

ISSR ANALYSIS. A total of 20 primers [i.e., $(\mathrm{AC})_{8} \mathrm{YG}$, $(\mathrm{AG})_{8} \mathrm{YC},(\mathrm{AC})_{8} \mathrm{YA},(\mathrm{AC})_{8} \mathrm{YT},(\mathrm{AG})_{8} \mathrm{YT},(\mathrm{GT})_{8} \mathrm{YG}$, $(\mathrm{TCC})_{5} \mathrm{RY},(\mathrm{GA})_{8} \mathrm{YC},(\mathrm{CA})_{8} \mathrm{RG}$, and $(\mathrm{GA})_{8} \mathrm{YG}$, reported by Fang and Roose, 1997, and ENEA7, ENEA8, ENEA12, ENEA13, ENEA14, ENEA21, ENEA34, ENEA36, ENEA45, and ENEA47 (Table 2) given by S. Lucretti of the Biotechnology and Agriculture Division (Ente per le Nuove tecnologie, l'Energia e l'Ambiente, Centro Ricerche Casaccia, Rome)] were used to amplify the DNA. The ISSR primers have been selected on the basis of their usefulness in published data (Fang and Roose, 1997; Siragusa et al., 2006, 2007) or previous experience. The primers were purchased from MWG-Biotech AG (Ebersberg, Germany).

Each amplification was performed in a $25-\mu \mathrm{L}$ reaction volume containing $20 \mathrm{~mm}$ Tris- $\mathrm{HCl}$ (pH 8.4), $50 \mathrm{~mm} \mathrm{KCl,} 2 \mathrm{~mm}$ $\mathrm{MgCl}_{2}, 800 \mu \mathrm{M}$ dNTP (dATP:dTTP:dCTP:dGTP in 1:1:1:1 ratio), $0.5 \mu \mathrm{M}$ of each primer, $1 \mathrm{U}$ of Platinum Taq polymerase (Invitrogen, Carlsbad, CA), and $30 \mathrm{ng}$ of template DNA. The amplification was performed in a 96-well GeneAmp PCR System 9700 (Applied Biosystems, Foster City, CA) equipped with a Hot Bonnet under the following cycle program: initial denaturation step for $4 \mathrm{~min}$ at $94^{\circ} \mathrm{C}$, followed by 36 cycles at $94{ }^{\circ} \mathrm{C}$ for $30 \mathrm{~s}$ (denaturation), $47^{\circ} \mathrm{C}$ to $60^{\circ} \mathrm{C}$ for $45 \mathrm{~s}$ (annealing), and $72{ }^{\circ} \mathrm{C}$ for $120 \mathrm{~s}$ (extension), followed by a final extension step at $72{ }^{\circ} \mathrm{C}$ for $7 \mathrm{~min}$. PCR-amplified DNA fragments were separated on a $1.5 \%$ agarose gel containing $1 \times$ TBE $(45 \mathrm{~mm}$ Tris-borate and $1 \mathrm{~mm}$ EDTA) and $0.5 \mu \mathrm{g} \cdot \mathrm{mL}^{-1}$ aqueous solution of ethidium bromide. About $25 \mu \mathrm{L}$ of reaction products with $5 \mu \mathrm{L}$ of loading buffer $(0.25 \%$ BFB, $40 \%$, w/v, sucrose $)$ were loaded onto the gel, which was run for $4 \mathrm{~h}$ at $100 \mathrm{~V}$. The gel was then visualized with a ultraviolet transilluminator at $300 \mathrm{~nm}$. To confirm the reproducibility of the banding patterns, the PCR experiments were repeated three times.

RAPD ANALYSIS. Twenty-two arbitrary decamer primers i.e., OPA01, OPAT 04, OPAT14, OPH04, OPH15, OPK04, OPM04, OPM06, OPN07, OPN14, OPO14, OPQ11, and P130 (reported by Coletta Filho et al., 1998) and UBC219, UBC234, UBC237, UBC239, UBC247, UBC251, UBC264, UBC266, and UBC272 (reported by Wang et al., 1999) were used for the amplification of DNA sequences. The primers were purchased from MWG-Biotech AG.

DNA amplification reactions were performed in a volume of $25 \mu \mathrm{L}$ with $20 \mathrm{~mm}$ Tris- $\mathrm{HCl}\left(\mathrm{pH} 8.4\right.$ ), $50 \mathrm{~mm} \mathrm{KCl,} 3 \mathrm{~mm} \mathrm{MgCl}_{2}$, $800 \mu \mathrm{M}$ dNTP, $0.4 \mu \mathrm{M}$ of each primer, $1 \mathrm{U}$ of Platinum Taq polymerase (Life Technologies, Grand Island, NY), and $30 \mathrm{ng}$ of template DNA. The amplification was performed in a 98-Well GeneAmp PCR System 9700 thermocycler (Applied Biosystems) equipped with a Hot Bonnet under the following cycle program: initial denaturation step for $90 \mathrm{~s}$ at $94{ }^{\circ} \mathrm{C}$, followed by 40 cycles at $94{ }^{\circ} \mathrm{C}$ for $1 \mathrm{~min}$ (denaturation), $35^{\circ} \mathrm{C}$ for $2 \mathrm{~min}$ (annealing), and $72^{\circ} \mathrm{C}$ for $2 \mathrm{~min}$ (extension), followed by a final extension step at $72{ }^{\circ} \mathrm{C}$ for $10 \mathrm{~min}$. PCR-amplified DNA fragments were visualized as described above. To confirm the reproducibility of the banding patterns, all analyses were repeated three times.

Data ANALYsis. Amplified bands from each primer were scored as present (1) or absent (0) for all cultivars studied. Only those bands showing consistent amplification were considered; smeared and weak bands were excluded from the analysis. Dice's (1945) coefficient of similarity $\left(D_{i j}\right)$ was determined between each pair of accessions. Dice's coefficient has been recommended for the evaluation of genetic similarities when using RAPD data (Lamboy, 1994). The genetic distance (GD) between two samples was calculated as: $G D=1-D_{i j}$. The estimates of similarity between cultivars were then used for cluster analysis by unweighted pair group method of arithmetic average (UPGMA; Sneath and Sokal, 1973) using NTSYS, version 2.02, for Windows (Rohlf, 1994). The Mantel test of genetic and geographic (Euclidian) distances was carried out using 250 permutations.

Additional statistics were computed to estimate the grade of polymorphism among cultivars studied. The average marker allele frequency $\left(\mathrm{p}_{\mathrm{i}}\right)$ for each primer and among all primers was calculated for each single accession and among all accessions. Genetic diversity $(\mathrm{H})$ of Nei (1973) and Shannon index $(S)$ (Lewontin, 1972) were used to summarize the data for molecular markers, and their standard deviations (SD) were indicated. The percentage of polymorphisms ( $\mathrm{Pp}$ ) was given as number of polymorphic loci/number of total loci, regardless of allele frequencies. The fixation index $\left(\mathrm{G}_{\mathrm{ST}}\right)$ was computed as a proportion of genetic diversity expressed between accessions coming from different geographic regions. From this, the gene flow $(\mathrm{Nm})$ was derived and interpreted according to McDermott and McDonald (1993). All calculations and analyses were conducted using POPGENE, version 1.31 (Yeh et al., 1999).

\section{Results}

A total of 558 reproducible and well-resolved band classes were observed in all lemon plants; 120 loci of these $(\mathrm{Pp}=$ $21.5 \%$ ) appeared polymorphic. When the analysis was carried out only for Sicilian accessions (excluding also the disputed 
Table 1. Lemon accessions analyzed and relatively more remarkable quality traits (Crescimanno et al., 1992).

\begin{tabular}{|c|c|c|c|}
\hline Accession & Sampling site ${ }^{\mathrm{z}}$ & Code & Remarkable quality traits $^{\mathrm{y}}$ \\
\hline Femminello comune & Palermo & FC1 & High juice production (33.8\%) (7.6.7.-7) \\
\hline Femminello comune & Palermo & FC2 & High juice production (38.3\%) (7.6.7.-7) \\
\hline Femminello Lo Porto & Palermo & FL & \\
\hline Femminello verdellifero & Santa Flavia (PA) & FV1 & High juice production (33.3\%) (7.6.7.-7) \\
\hline Femminello femminino & Santa Flavia (PA) & $\mathrm{FF}$ & $\begin{array}{c}\text { Low seeds number per fruit (4.3) (7.7.1.-2); } \\
\text { high juice production }(34.4 \%)(\mathbf{7 . 6 . 7 . - 7 )}\end{array}$ \\
\hline Femminello Pozzetti & Lascari (PA) & FP & Citrus wilt tolerance (10.12.11.-1) \\
\hline Femminello comune & Mandanici (ME) & FC4 & High acidity juice (7.80) (8.5.1) \\
\hline Femminello comune & Roccalumera (ME) & FC5 & High acidity juice (7.30) (8.5.1) \\
\hline Femminello paddaru & Roccalumera (ME) & FD & High juice production (35.2\%) (7.6.7.-7) \\
\hline Femminello russiddaru & Roccalumera (ME) & FR & \\
\hline Femminello cucuzzaro & Roccalumera (ME) & FU1 & \\
\hline Femminello Germanà & Capo d'Orlando (ME) & FG & \\
\hline Femminello Pettineo & Pettineo (ME) & FO & $\begin{array}{l}\text { Low seeds number per fruit (2.2) (7.7.1.-1); } \\
\text { high juice production }(41.8 \%)(\mathbf{7 . 6 . 7 . - 7 )} \\
\text { high acidity juice }(7.27)(\mathbf{8 . 5 . 1})\end{array}$ \\
\hline Femminello famularo & Rometta (ME) & FF3 & Citrus wilt tolerance (10.12.11.-1) \\
\hline Femminello cucuzzaro & Brolo (ME) & FU2 & \\
\hline Femminello famularo & Brolo (ME) & FF4 & Citrus wilt tolerance (10.12.11.-1) \\
\hline Femminello precoce & Brolo (ME) & $\mathrm{FE}$ & \\
\hline Femminello sfusato & Brolo (ME) & $\mathrm{FN}$ & $\begin{array}{l}\text { High juice production }(40.6 \%)(\mathbf{7 . 6 . 7 . - 7 )} \\
\text { high acidity juice }(7.23) \mathbf{( 8 . 5 . 1 )}\end{array}$ \\
\hline Femminello verdellifero & Brolo (ME) & FV2 & High acidity juice (7.10) (8.5.1) \\
\hline $\begin{array}{l}\text { Femminello fior d'arancio } \\
\text { (or zagara bianca) }\end{array}$ & Catania (CT) & FA & $\begin{array}{l}\text { High juice production }(33.2 \%) \text { (7.6.7.-7); } \\
\text { citrus wilt tolerance (10.12.11.-1) }\end{array}$ \\
\hline Femminello siringo & Siracusa (SR) & FS & $\begin{array}{l}\text { Low seeds number per fruit (4.6) (7.7.1.-2); } \\
\text { high juice production }(43.9 \%)(\mathbf{7 . 6 . 7 . - 7 )} \\
\text { high acidity juice (7.03) (8.5.1) }\end{array}$ \\
\hline Monachello non rifiorente & Fiumefreddo (ME) & $\mathrm{MN}$ & $\begin{array}{l}\text { Low seeds number per fruit (4.2) (7.7.1.-2); } \\
\text { citrus wilt tolerance (10.12.11.-1) }\end{array}$ \\
\hline Monachello Sant'Antonio & Messina & MS & $\begin{array}{l}\text { Low seeds number per fruit (4.8); citrus wilt } \\
\text { tolerance (10.12.11.-1) }\end{array}$ \\
\hline Femminello - Monachello quattrocchi & Catania & MQ & Citrus wilt tolerance (10.12.11.-1) \\
\hline Lunario & Villagrazia (PA) & LV & \\
\hline Lunario spinoso & Fiumefreddo (ME) & LT & $\begin{array}{l}\text { Low seeds number per fruit (3.9) (7.7.1.-1); } \\
\text { high acidity juice (7.20) (8.5.1) }\end{array}$ \\
\hline Femminello Favazzina & Reggio Calabria & FV & \\
\hline Femminello a foglia larga & Reggio Calabria & FW & $\begin{array}{l}\text { High juice production }(34.0 \%)(\mathbf{7 . 6 . 7 . - 7 )} \\
\text { high acidity juice }(7.50)(\mathbf{8 . 5 . 1})\end{array}$ \\
\hline Femminello comune & Salerno & FC7 & \\
\hline Frost Eureka & Riverside (U.S.A.) & $\mathrm{EF}$ & \\
\hline Eureka Messina lemon & Messina & EM & \\
\hline
\end{tabular}

ㄱhe province of the sampling site is showed in brackets; CT $=$ Catania, ME = Messina, PA $=$ Palermo, $\mathrm{SR}=$ Siracusa.

ynternational Plant Genetic Resources Institute code of the quality traits is signed in bold type. 


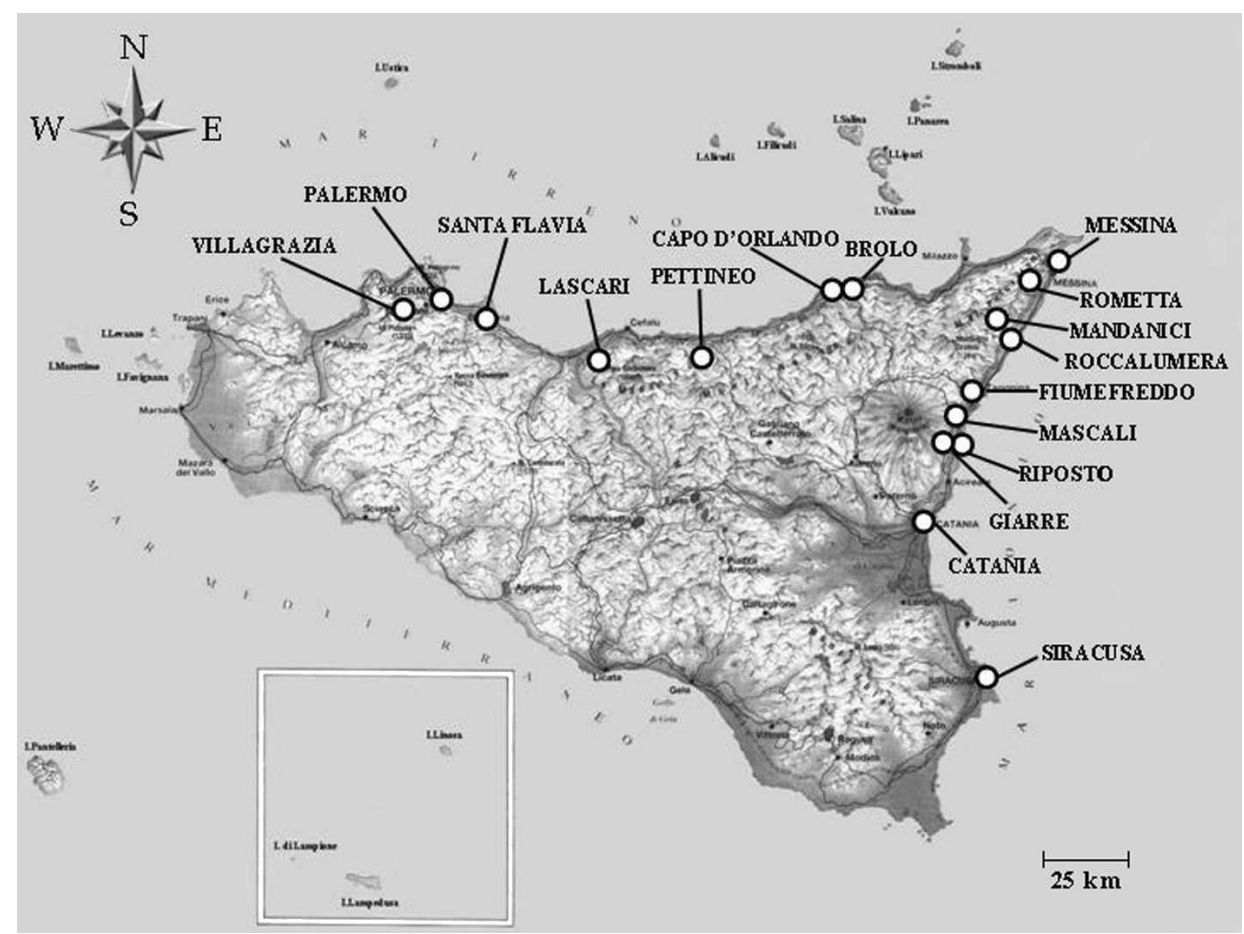

Fig. 1. Geographic localization of sampling sites of Sicilian lemon accessions analyzed.

classes) were identified with RAPD primers, with an average of 3.1 polymorphic band classes per primer. Some polymorphisms identified with the RAPD primer OPM04 are shown in Fig. 3.

Dice's similarity coefficient was used to carry out cluster analysis and to generate a dendrogram showing the relationships among the selected accessions (Fig. 4). The dendrogram showed two main groups, one including most 'Femminello' accessions (group 1) and another including the accessions 'Monachello Sant' Antonio' (MS), 'Lunario' (LV), 'Femminello femminino' (FF), and 'Femminello famularo a foglia larga' (FF1; group 2), having a genetic similarity of 0.97 . In group 1 , accessions 'Frost Eureka' and 'Eureka Messina lemon' appeared different and stood alone, close to the root of the relationship group. Subgroup $1 \mathrm{~A}$, having a genetic similarity higher than 0.99 , included only the 'Femminello' accessions and contained all 'Femminello' from other

Table 2. Sequences and annealing temperatures of ENEA primers used for ISSR analysis.

\begin{tabular}{lcc}
\hline Primer name & Primer sequence $\left(5^{\prime}-3^{\prime}\right)$ & Annealing temp. $\left({ }^{\circ} \mathrm{C}\right)$ \\
\hline ENEA7 & GGTC $(\mathrm{CA})_{7}$ & 56 \\
ENEA8 & $\mathrm{CAGC}(\mathrm{AC})_{7}$ & 56 \\
ENEA12 & $\mathrm{CCAT}(\mathrm{GT})_{7}$ & 53 \\
ENEA13 & $\mathrm{GCA}(\mathrm{AC})_{7}$ & 53 \\
ENEA14 & $\mathrm{GGG}(\mathrm{AC})_{7}$ & 53 \\
ENEA21 & $(\mathrm{GA})_{8} \mathrm{GG}$ & 54 \\
ENEA34 & $(\mathrm{ACC})_{6} \mathrm{CC}$ & 56 \\
ENEA36 & $\mathrm{CC}(\mathrm{ATG})_{6}$ & 56 \\
ENEA45 & $\mathrm{AA}(\mathrm{CT})_{8}$ & 52 \\
ENEA47 & $\mathrm{AG}(\mathrm{CA})_{8}$ & 53 \\
\hline
\end{tabular}

'Eureka Messina lemon'), the percentage of polymorphic loci was reduced to $17.9 \%$.

The 20 ISSR primers used in this analysis gave rise to 251 well-resolved band classes, ranging from $200 \mathrm{bp}$ [primer $(\mathrm{GA})_{8} \mathrm{YG}$ ] to $2.5 \mathrm{~Kb}$ [primer $(\mathrm{CA})_{8} \mathrm{RG}$ ] in size. The number of ISSR bands obtained for each primer varied from 8 [primer $(\mathrm{AG})_{8} \mathrm{YG}$ ] to 18 [primer $(\mathrm{AC})_{8} \mathrm{YT}$ ], with an average of 12.1 bands per primer. Fifty-two polymorphic band classes $(9.3 \%$ of the total amplified band classes) were identified with ISSR primers, with an average of 2.6 polymorphic band classes per primer. Some polymorphisms identified with the ISSR primer ENEA34 are shown in Fig. 2.

The RAPD primers produced 307 reproducible band classes, ranging from $300 \mathrm{bp}$ (primer OPN14) to $2.5 \mathrm{~kb}$ in size (primer OPM04). The number of RAPD bands obtained for each primer varied from 9 (with the primer OPO14) to 18 (with the primer OPM04), with an average of 13.4 bands per primer. Sixty-eight polymorphic band classes $(12.2 \%$ of the total amplified band
Italian regions, 'Femminello common' from Campania (FC7), 'Femminello a foglia larga' (FW), and 'Femminello Favazzina' (FV) from Calabria. In this subgroup, 10 accessions, including 'Femminello common' from Salerno (FC7), were not distinguished, showing the typical Sicilian 'Femminello' profile. Similarly, 'Femminello comune' from Mandanici (FC4) with 'Femminello comune' from Roccalumera (FC5), 'Femminello verdellifero' from Brolo (FV2) with 'Femminello verdellifero' from Giarre (FV3), and 'Femminello Pettineo' (FO) with 'Femminello Favazzina' (FV) appeared indistinguishable. The remaining accessions were separated from each other, clustering in groups that cannot be explained by their likely area of origin. The Mantel test was carried out to confirm this hypothesis. A very low normalized Mantel statistic $Z$ value was obtained (matrix correlation $r=0.11$ ), with a probability random $Z \geq$ observed $Z=0.50$.

The total Nei's genetic diversity $\left(\mathrm{H}_{\mathrm{T}}\right)$ for Sicilian accessions was $0.037 \pm 0.002$. It was lower if calculated only for 'Femminello' accessions $(0.019 \pm 0.006)$. An additional measure for genetic variation was obtained from the Shannon index, a genetic diversity index suitable when dominant markers are used (Dawson et al., 1995). $S$ value was $0.060 \pm 0.005$ for all Sicilian accessions analyzed, and it was $0.034 \pm 0.008$ when only 'Femminello' accessions were considered.

An analysis of gene diversity in Sicilian 'Femminello' accessions was carried out in the three principal growing areas (Palermo, Messina, and Catania). The accession 'Femminello siringo' (FS), unique to the Siracusa zone, was excluded from this analysis.

Low gene diversity was found in all three regions analyzed, with the greatest value in the area of Palermo $(\mathrm{h}=0.020 \pm$ $0.087)$, followed by Messina $(h=0.016 \pm 0.069)$ and Catania $(\mathrm{h}=0.011 \pm 0.059)$. The greatest number of polymorphic loci was identified in Messina accessions $(\mathrm{Pp}=8.5 \%)$, whereas Palermo 


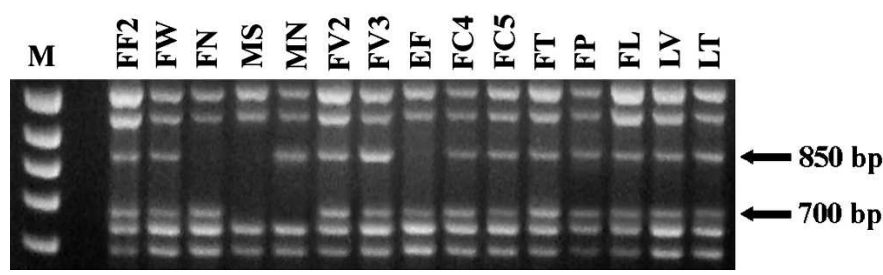

Fig. 2. ISSR profiles amplified from DNA of lemon accessions analyzed using primer ENEA34. $\mathrm{M}=100$-bp DNA ladder, FF2 = 'Femminello famularo a foglia stretta', FW = 'Femminello a foglia larga', $\mathrm{FN}=$ 'Femminello sfusato', $\mathrm{MS}=$ 'Monachello Sant'Antonio', MN = 'Monachello non rifiorente', FV2 = 'Femminello verdellifero', FV3 = 'Femminello verdellifero', EF = 'Frost Eureka', FC4 = 'Femminello comune', FC5 = 'Femminello comune', FT = 'Femminello tondo precoce', FP = 'Femminello Pozzetti', FL = 'Femminello Lo Porto', LV = 'Lunario', and LT = 'Lunario spinoso'.

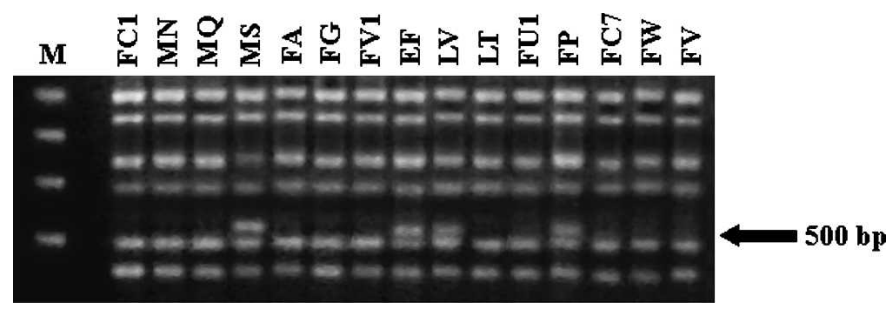

Fig. 3. RAPD profiles amplified from DNA of lemon accessions analyzed using primer OPM04. $\mathrm{M}=123$-bp DNA ladder, FC1 = 'Femminello comune', $\mathrm{MN}=$ 'Monachello non rifiorente', $\mathrm{MQ}=$ 'Monachello quattrocchi', MS = 'Monachello Sant'Antonio', FA = 'Femminello fior d'arancio', FG = 'Femminello Germanà', FV1 = 'Femminello verdellifero', EF = 'Frost Eureka', LV = 'Lunario', LT = 'Lunario spinoso', FU1 = 'Femminello cucuzzaro', FP = 'Femminello Pozzetti', FC7 = 'Femminello comune', FW = 'Femminello a foglia larga', and FV = 'Femminello Favazzina'. and Catania areas showed lower values $(\mathrm{Pp}=5.8 \%$ and $4.5 \%$, respectively). The average variation within samples $\mathrm{H}_{\mathrm{S}}$ was $0.012 \pm 0.001$.

Genetic distances between accessions coming from Palermo and Messina was the lowest (0.003), whereas the GDs between Catania accessions and Palermo and Messina accessions were 0.006 and 0.004 , respectively.

The fixation index $\left(\mathrm{G}_{\mathrm{ST}}=0.42\right)$ showed that the observed genetic variability could be attributed slightly more to withinarea accession differences than to differences among the three areas. As expected, the estimated gene flow was extremely low $(\mathrm{Nm}=0.69)$.

Some markers were found to be associated with the different areas. The 750-bp fragment amplified from the RAPD primer OPH15 was principally present in the Messina area accessions, whereas an 1850-bp fragment amplified from the RAPD primer OPH04 was absent only in Messina accessions. Three fragments were commonly amplified in the accessions growth on the North coast of the island: the 550-bp fragment amplified from the RAPD primer OPH04, and the 650- and 1150-bp fragments from the ISSR primers $(\mathrm{AC})_{8} \mathrm{YG}$ and $(\mathrm{GA})_{8} \mathrm{YC}$, respectively. The 1150-bp fragment was also amplified in all accessions from Reggio Calabria, demonstrating the most probable route of gene flow from the island to the continent.

\section{Discussion}

Lemon characterization studies have already been carried out to examine the genetic diversity among the most important cultivars in some growing areas and to detect phylogenetic relationships between lemon and other Citrus species and Citrus-related genera.

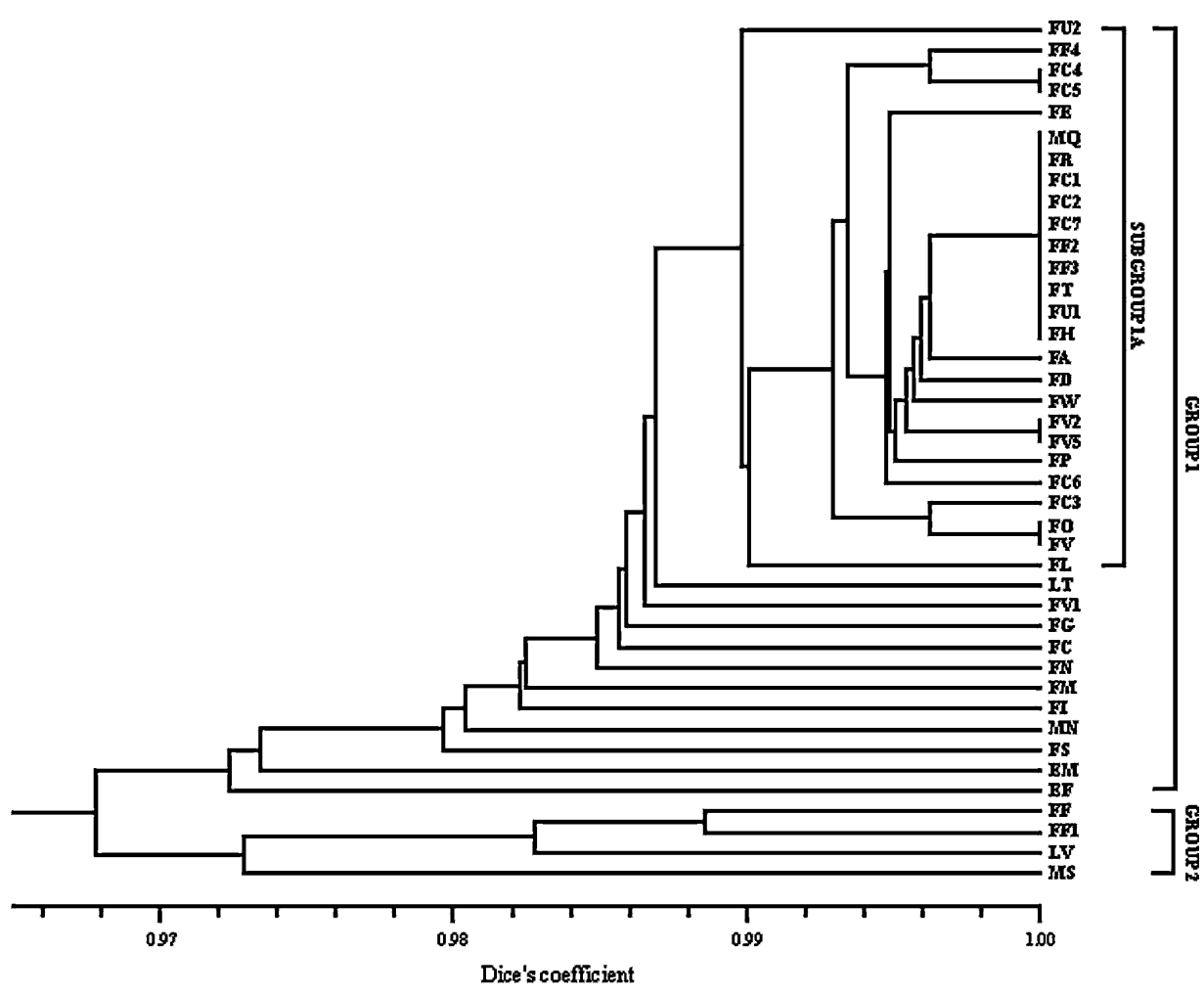

Fig. 4. UPGMA dendrogram of the lemon accessions obtained from the Dice's coefficient similarity matrix using ISSR and RAPD markers data.
The use of molecular markers surely gave important guidance to these studies. Microsatellites, ISSR, and RAPD were successfully used to show relationships among individuals of the same or closely related species and also among more distantly related taxa.

In all the studies of phylogenetic relationships within the genus Citrus, lemon cultivars always showed high levels of heterozygosity (Barkley et al., 2006; Federici et al., 1998; Gulsen and Roose, 2001b; Nicolosi et al., 2000; Torres et al., 1978). Furthermore, Fang and Roose (1997) found a much higher proportion of unique PCR-amplified fragments in lemon cultivars than sweet orange and grapefruit cultivars. On the contrary, when lemon accessions were analyzed, a low level of genetic variability was found (Gulsen and Roose, 2001a). This was also confirmed when Campania lemon germplasm was analyzed, showing high genetic similarity levels even if the analyzed cultivars appeared phenotypically different. 
In this study, we carried out the analysis of the genetic diversity of Sicilian lemon germplasm using two multilocus PCR-based techniques, ISSR and RAPD. The usefulness and reliability of these molecular markers has already been proven in several other lemon fingerprinting studies (Capparelli et al., 2004; Fang and Roose, 1997). The data obtained have been used to find genetic relationships among different cultivars and landraces commonly cultivated in this region and to assess the genetic status of lemon germplasm on the island.

Our analyses showed a low grade of polymorphism among all the analyzed genotypes, even though the pool represented by the unique accessions was broad enough (22 of 36 Sicilian genotypes). Also, if the observed morphological differentiation of Sicilian lemon landraces was higher than the identified genetic diversity, these data reflect the richness of lemon germplasm present in Sicily at the moment and suggest that it originated from a common ancestor, probably a 'Femminello' plant, from bud mutation. The reproductive characteristics of the lemon (nucellar embryony), the conservative selection criteria of Sicilian traditional agriculture, and genetic isolation (shown by the low $\mathrm{Nm}$ and by a very low correlation between genetic and geographical relationships) explain the finding of low levels of heterozygosity. On the contrary, plants belonging to group 2 showed a genetic diversity $(\mathrm{GD}=0.03)$ with the 'Femminello' group (group 1) comparable to the diversity identified by Federici et al. (1998) between the cultivars Frost Lisbon and Eureka. Effectively, 'Monachello Sant'Antonio' (MS) and 'Lunario' (LV) belong to two groups with many phenotypic traits different from 'Femminello' (for example, citrus wilt disease tolerance). The other two plants belonging to group 2, 'Femminello femminino' (FF) and 'Femminello famularo a foglia larga' (FF1), until now considered belonging to the cultivar Femminello, appeared instead genetically very different.

'Monachello non rifiorente' (MN) and 'Lunario spinoso' (LT) also appeared separated from subgroup 1A, even though more strictly related. 'Monachello' and 'Lunario' accessions appeared scattered in the UPGMA dendrogram. It warrants consideration that these cultivars could be constituted from genetically very different genotypes, originated several times from different mutational or hybridization events. It explains the wide range of morphotypes constituting these cultivars, but only partially agrees with the hypothesis that Monachello cultivar is a lemon $\times$ citron (Citrus medica L.) hybrid (Morton, 1987). 'Monachello quattrocchi' (MQ) was not discriminated. This was expected for the accession 'quattrocchi,' which is now considered a 'Femminello' accession, even though in some areas of Catania it is still called "monachello" because of its high tolerance to citrus wilt disease. The certified 'Eureka' (EF) and the disputed 'Eureka Messina lemon' (EM) also appeared different from the 'Femminello' group and slightly different from each other.

Our analyses also confirmed three other important facts shown by previous phenotypic analysis (Crescimanno et al., 1992). First, accessions coming from the southeast area of Sicily were shown to be more different from other areas (GDs = 0.006 and 0.004 between Catania accessions and Palermo and Messina accessions, respectively). This could be explained with some genetic pool isolation of local accessions. Second, the accession 'Lunario spinoso' (LT) appeared tightly associated with the 'Femminello' group and, especially, with 'Femminello verdellifero' (FV1). Third, the accession 'Femminello innesto palermitano' (FI) appeared very different from other 'Femminello' accessions. On the contrary, the accessions 'Femminello famularo a foglia stretta' (FF2) and 'Femminello comune' from Mandanici (FC4), which appeared identical by phenotypic analysis reported from Crescimanno et al. (1992), were differentiated by molecular markers.

Furthermore, 'Femminello' accessions from other Italian regions appeared similar to the typical Sicilian 'Femminello' profile, providing evidence for movement and exchange of germplasm from the island to the continent.

In conclusion, the molecular investigation carried out in this study allowed an evaluation of the degree of genetic differentiation seen in probably one of the most important clusters of C. limon germplasm in the world. 'Femminello', 'Monachello', and 'Lunario' groups appeared to be effectively different cultivars, each composed of a phenotypically and genotypically diverse range of plants. Much data $\left(\mathrm{G}_{\mathrm{ST}}\right.$ and $\left.\mathrm{Nm}\right)$ showed that genetic isolation preserved several genetically different landraces, especially in the southeastern area of Sicily, but the situation of the Sicilian lemon cultivation suggest that they could quickly decrease. Actually, Citrus cultivation in Sicily is going through a long crisis period, and the reduced level of gene flow found among populations may decrease the potential for species persistence in face of biotic and abiotic environmental changes (Soulè, 1980). In this situation, collecting local accessions is of great importance for ecological (maintaining rare genes) and cultural (saving landraces) reasons.

Analysis of the genetic variability of lemon landraces and organization of a molecular characterization system could form the basis for future germplasm conservation programs and may represent a useful tool in planning genetic breeding aimed at developing new and improved lemon cultivars.

\section{Literature Cited}

Barkley, N.A., M.L. Roose, R.R. Krueger, and C.T. Federici. 2006. Assessing genetic diversity and population structure in a citrus germplasm collection utilizing simple sequence repeat markers (ISSR). Theor. Appl. Genet. 112:1519-1531.

Capparelli, R., M. Viscardi, M.G. Amoroso, G. Blaiotta, and M. Bianco. 2004. Inter-simple sequence repeat markers and flow cytometry for the characterization of closely related Citrus limon germplasm. Biotechnol. Lett. 26:1296-1299.

Coletta Filho, H.D., M.A. Machado, M.L.P.N. Targon, M.C.P.Q.D.G. Moreira, and J. Pompeu, Jr. 1998. Analysis of the genetic diversity among mandarins (Citrus spp.) using RAPD markers. Euphytica 102:133-139.

Cottone, C., M. Viscardi, S. Boiano, I. Santangelo, L. D’Apice, L. Colantonio, R. Capparelli, D. Iannelli, and C. Novello. 1996. Analisi mediante citofluorimetria e RAPD-PCR di undici cloni di limone. Annali della Facoltà di Scienze Agrarie dell'Università degli Studi di Napoli Federico II 4. 15:39-54.

Crescimanno, F.G., F. De Pasquale, M.A. Germanà, and A. Motisi. 1992. Indagine sul germoplasma del limone [Citrus limon (L.) Burm. F.] in Italia. Atti del congresso germoplasma frutticolo, salvaguardia e valorizzazione delle risorse genetiche. Alghero 2125:455-466.

Dawson, I.K., A.J. Simons, R. Waugh, and W. Powell. 1995. Diversity and genetic differentiation among subpopulations of Gliricidia sepium revealed by PCR-based assays. Heredity 75:10-18.

Dice, L.R. 1945. Measures of the amount of ecologic association between species. Ecology 26:297-302.

Doyle, J.J. and J.L. Doyle. 1987. A rapid DNA isolation procedure from small quantities of fresh leaf tissue. Phytochem. Bull. 19:11-15. 
Fang, D.Q. and M.L. Roose. 1997. Identification of closely related Citrus cultivars with inter-simple sequence repeat markers. Theor. Appl. Genet. 95:408-417.

Federici, C.T., D.Q. Fang, R.W. Scora, and M.L. Roose. 1998. Phylogenetic relationships within the genus Citrus (Rutaceae) and related genera as revealed by RFLP and RAPD analysis. Theor. Appl. Genet. 96:812-822.

Forte, V. 1999. Il limone scelte fondamentali, tecnica culturale, difesa, commercializzazione e consumo. Edagricole. 4th ed. Collana di manuali tecnici, Bologna, Italy.

Gulsen, O. and M.L. Roose. 2001a. Lemons: Diversity and relationships with selected Citrus genotypes as measured with nuclear genome markers. J. Amer. Soc. Hort. Sci. 126:309-327.

Gulsen, O. and M.L. Roose. 2001b. Chloroplast and nuclear genome analysis of the parentage of lemons. J. Amer. Soc. Hort. Sci. 126:210-215.

Lamboy, W.F. 1994. Computing genetic similarity coefficients from RAPD data: The effects of PCR artifacts, p. 31-37. In: PCR methods and applications. Cold Spring Harbor Laboratory Press, Cold Springs Harbor, NY.

Lewontin, R.C. 1972. The apportionment of human diversity. Evol. Biol. 6:381-398.

Mariniello, L., M.G. Sommella, A. Cozzolino, P. Di Pierro, D. Ercolini, and R. Porta. 2004. Identification of Campania Citrus limon L. by random amplified polymorphic DNA markers. Food Biotechnol. 18(3):289-297.

McDermott, J.M. and B.A. McDonald. 1993. Gene flow in plant pathosystems. Annu. Rev. Phytopathol. 31:353-373.

Morton, J.F. 1987. Lemon, p. 160-168. In: J.F. Morton (ed.). Fruits of warm climates. Florida Flair Books, Miami, FL.

Nei, M. 1973. Analysis of gene diversity in subdivided populations. Proc. Natl. Acad. Sci. USA 70:3321-3323.

Nicolosi, E., Z.N. Deng, A. Gentile, S. La Malfa, G. Continella, and E. Tribulato. 2000. Citrus phylogeny and genetic origin of important species as investigated by molecular markers. Theor. Appl. Genet. 100:1155-1166.

Rohlf, F.J. 1994. NTSYS: Numerical taxonomy and multivariate analysis system, version 2.02. State University of New York, Stoney Brook, NY.

Russo, F. and P. Spina. 1985. Varietà coltivate, p. 117-156. In: G. Cutuli, E. Di Martino, V. Lo Giudice, L. Pennini, G. Raciti, F. Russo, A. Scuderi, and P. Spina (eds). Trattato di agrumicoltura. 1st ed. Edagricole, BolognaItaly.

Sambrook, J., E.F. Fritsch, and T. Maniatis. 1989. Molecular cloning. A laboratory manual. 2nd ed. Cold Spring Harbor Laboratory Press, Cold Spring Harbor, NY.

Saunt, J. 2000. Citrus varieties of the world. 2nd ed. Sinclair International, Norwich, UK.

Siragusa, M., A. Carra, L. Salvia, A.M. Puglia, F. De Pasquale, and F. Carimi. 2007. Genetic instability in calamondin (Citrus madurensis Lour.) plants derived from somatic embryogenesis induced by diphenylurea derivatives. Plant Cell Rpt. 26:1289-1296.

Siragusa, M., F. De Pasquale, L. Abbate, and N. Tusa. 2006. Identification of sour orange accessions and evaluation of their genetic variability by molecular marker analyses. HortScience 41(1):84-89.

Sneath, P.H. and R.R. Sokal. 1973. Numerical taxonomy: The principles and practice of numerical classification. Freeman, San Francisco.

Soulè, M.E. 1980. Thresholds for survival: Maintaining fitness and evolutionary potential, p. 151-169. In: M.E. Soulè and B.A. Wilkok (eds.). Conservation biology: An evolutionary-ecological approach. Sinauer Associates, Sunderland, MA.

Torres, A.M., R.K. Soost, and U. Diedenhofen. 1978. Leaf isozymes as genetic markers in Citrus. Amer. J. Bot. 65:869-881.

Wang, Y., J. Chen, J. Lu, and O. Lamikanra. 1999. Randomly amplified polymorphic DNA analysis of Vitis species and Florida bunch grapes. Scientia Hort. 82:85-94.

Yeh, F.C., R.C. Yang, and T. Boyle. 1999. POPGENE, Version 1.31. Center for International Forestry Research and University of Alberta, Edmonton, Alberta, Canada. 